\title{
Is Trade Integration Leading to Regionalization? Evidence from Cross-Country Network Analysis
}

\author{
C.T. Vidya ${ }^{1+}$, K.P. Prabheesh ${ }^{2}$, Saahil Sirowa ${ }^{2}$ \\ ${ }^{1}$ Centre for Economic Social Studies Hyderabad, India \\ ${ }^{2}$ Indian Institute of Technology Hyderabad, India
}

\begin{abstract}
The present paper empirically analyzes the structural change in world trade over the last two decades by examining trade integration, leadership, and regionalization through a network model. We selected 50 countries encompassing both developed and developing nations and grouped them into 9 regions for 1990, 1992, 2000, 2010, and 2017. We have undertaken two principal analyses: (i) trade intensity indices and regionalization and (ii) linking trade intensity with network analysis. Therefore, this paper reaches a trade-off condition. The major findings of the study are as follows: (i) regional integration is stronger and has increased over the years; (ii) trade regionalization is primarily dominated by developed regions; (iii) trade liberalization has reduced the gap between the center and periphery; (iv) emerging Asian economies have developed as leaders and export hubs of goods in the global market; (v) trade liberalization has transformed and reshaped the world trade structure; and (vi) trade liberalization has not driven the lessening geodesic distance and transport costs from trade, and thus, there are no major gains for many countries.
\end{abstract}

Keywords: Trade Intensity Indices, Network Analysis, Regionalization, Trade Integration, Trade Introversion.

JEL Classifications: F14, F15, D85

Received 19 August 2019, Revised 1 December 2019, Accepted 16 December 2019

\section{Introduction}

Over the years, most countries across the globe have increasingly opened their economies up to international trade. According to numerous previous studies ${ }^{1)}$, trade and globalization have brought tremendous benefits to many countries. Further, the international economic system has been undergoing considerable changes in trade patterns, thus reshaping the structure of global trade. This transition was favored by many factors, such as the growth of services trade, growing global value chains (GVCs), technology and digitization, a gradual reduction in tariffs, and the emergence of emerging market economies (EMEs). $\left.{ }^{2}\right)$

\footnotetext{
+Corresponding Author: C.T. Vidya

Assistant Professor, Centre for Economic Social Studies, Nizamiah Observatory Campus, Begumpet, Hyderabad, India, Tel: +91-9177549655, Email: vidya@cess.ac.in

Co-Author: K.P. Prabheesh

Associate Professor, Indian Institute of Technology Hyderabad, India. Email:prabheesh@iith.ac.in

Co-Author: Saahil Sirowa

Undergraduate Student, Indian Institute of Technology Hyderabad, Hyderabad, India
} 
The 2008 global financial crisis marked a turning point in global trade that was characterized by rising protectionism, regionalism, and a reluctance to adopt the trade reforms of the World Trade Organization (WTO). The new tariff war between the United States (US) and China also perpetuated high trade tension and exacerbated the sharp deceleration of world trade over the past year. Inconclusive trade negotiations further intensified trade restrictions, impacting developing economies through both direct and indirect channels (UNCTAD, 2019). In the last two decades, many emerging countries have opened up their economies and expanded their connections to world trade networks (WTNs). Emerging countries like China and India could affect and reshape world trade flows. Assuredly, they created abrupt pressure in global trade structures, traversing into further reshaping, intensification, and regionalization.

World trade demonstrates considerable growth; these patterns are depicted in Figure 1. International trade as a percentage of gross domestic products (GDPs) for the seven regions of the world shows a significant increase in the trade since 1990. Especially, the shares of trade to GDP for the South and East Asia and the Pacific regions have increased significantly over time, indicating their major roles in global trade. Figure 1 also indicates significant trade decline in all regions in 2009 owing to the global financial crisis, signifying that all regions were exposed to the same shocks. However, during the post-crisis period, there was a slight increase in trade in the European and Central Asian regions, whereas the overall trend in other regions showed a deceleration of trade post-financial crisis. Given this scenario, it is important to understand the level of interconnectedness between countries in these regions. Therefore, this study aims to discover a solution to the following important questions specifically related to trade among countries. (i) What role does trade play in the growing interdependence of countries? (ii) Which are the "center-periphery" economies in the trade network? (iii) Which are the export hubs and local supplier countries in the trade network? (iv) Is there any transition from center to periphery and vice versa over the years? (v) Has proximity increased or improved within the trade network over the years? (vi) Is trade leadership still centered in the advanced countries? (vii) Is regionalization occurring in certain countries?

Both the new trade theory (Krugman 1981, Melitz 2003) and the theory of new economic geography (Krugman 1991, Baldwin and Okubo 2006) theoretically support the interconnectedness of countries established by trade and its network. A fall in the cost of trade leads to increased geographical concentration, agglomeration, and fragmentation of the production process. However, the extent to which trade costs have prompted the concentration of the production process needs to be examined (WTO 2008). There is a dearth in literature that addresses the issues linking trade integration, trade leadership, and regionalization-as viewed through the lens of

1) See Maddison (2005), Johnson (2002).

2) It has been mentioned in the works of several works, however for details refer Maattoo et al. (2013), Baldwin and Venables (2013), World Bank (2017), and Hoekman (2015). 
network analysis. Therefore, we use the network analysis approach to address the above issues. A network measures the interlinkages within trade through centrality, density, betweenness, clustering, and closeness.

Figure 1. Trade as \% of GDP in select regions of the world, 1990 2017

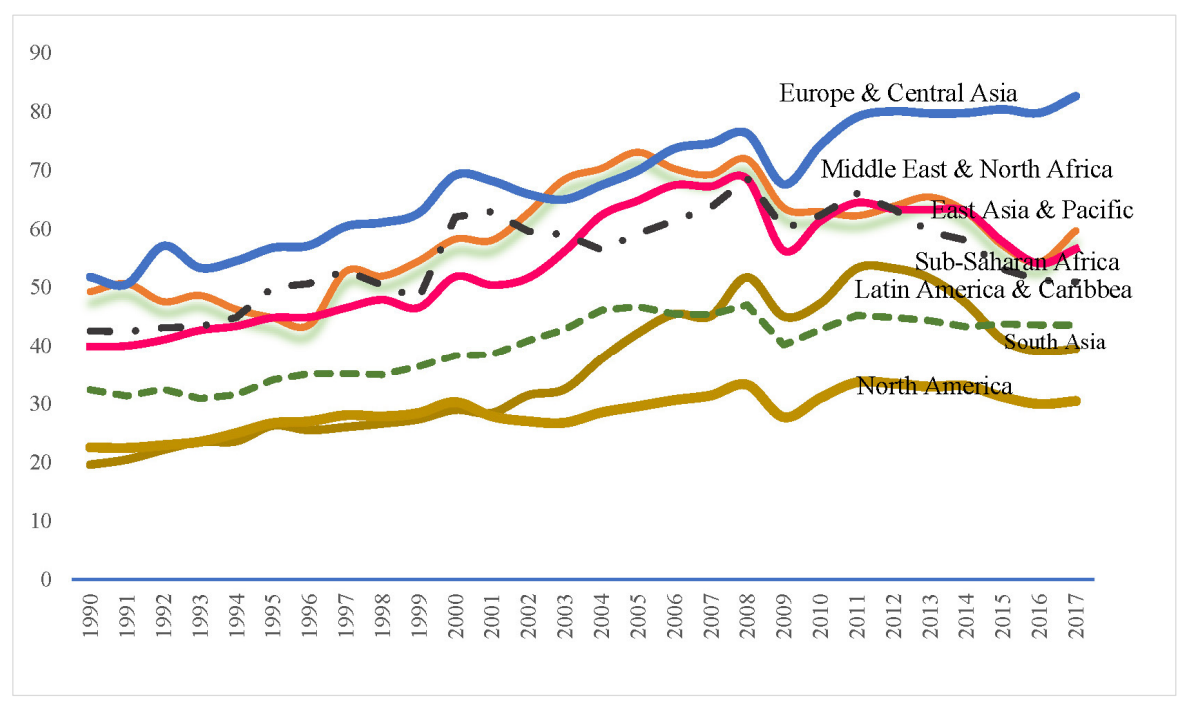

(Source) Author's creation from World Development Indicators.

Our study supplements existing works that link international trade and network analysis such as De Bendictis and Tajoli (2011), Kali and Reyes (2017), and Fagiolo et al. (2007). Similarly, studies that combine trade regionalization and network analysis are Lapadre and Tajoli (2014), Hamanaka (2015), and Nguyen et al. (2016). However, these studies lack an examination of: (i) the complexity of trade networks regarding the "center" and "periphery" in the context of trade liberalization; (ii) the export performance of emerging economies and their role in "reshaping" the world trade structure; (iii) the repositioning of the center-periphery in the WTN; and (iv) an exploration of trade regionalization and leadership among the largest sample countries, especially from the perspective of various regions. There are a few attempts to consider the last point, namely by Lapadre and Tajoli (2014) in the context of BRICS region and by Nguyen et al. (2016) in the context of the ASEAN+3.

Based on the given facts, we presume that by linking trade integration, leadership, and regionalization-we can explain the dynamics embedded in trade integration and regionalization. Trade liberalization is expected to reshape the WTN structure because, in a highly fragmented trade relationship, the foreign value-added in exports becomes intense and dominant (Amador and Cabral 2016). Hence, the center and periphery relationship turn out to be more complex and densely connected that previously assumed. The centrality measures of betweenness and 
closeness among the countries are expected to decline over a period as the average number of trading partners of each country increases, which may result in a reduction in transportation and communication costs due to trade liberalization and globalization (Krugman 1991). Moreover, interventions of institutional mechanisms such as the WTO also facilitate trade linkages. In line with the new trade theories, fragmentation and spatial redistribution of the production process at the global level drives the restructuring, reshaping, and repositioning of world trade. The above study suggests that many emerging Asian economies were repositioned to the center and became export hubs. According to Ottavino (2011), trade liberalization also brings forth spatial polarization between the center and the periphery. As such, some emerging economies lead and become concentrated, while others remain static. Therefore, the present study assumes that high intra-regional import preferences may lead to low trade intensity and trade introversion. Hence, each country's structural pattern plays a crucial role in determining trade intensities.

The rest of this paper is structured as follows. Section 2 presents a summary of literature on network and trade integration. Sections 3 and 4 discuss the data and methodology. Section 5 discusses the empirical results. Section 6 concludes.

\section{Literature Review}

In this section, we divide the literature broadly into studies related to the application of network analysis of trade and trade integration. There exists a considerable body of literature on issues of socio-economic systems in a framework using the tools of network analysis. "The network is a mathematical representation of the state of a system at a given point in time in terms of nodes and links" (Fagiolo et al. 2007). The research on networks is not a novel idea of recent times. It is more often applied in sociology, psychology, and economics in the form of social network analysis to analyze relationships among social entities, and patterns and their implications. ${ }^{3)}$ In this paper, we examine the applications of the network within the purview of international trade. The available literature can be divided into two major strands. The first group of studies emerged during the period between 1980 and 1990 and examined the center and periphery relationship in international trade among countries and the role of protectionism. The second group of studies, which were produced from the end of the 1990s to today, emphasizes the fragmentation of production and diversified markets around the globe using new trade theory.

3) Some of the seminal works in this field include theory and its applications in sociology (Wasserman and Faust, 1994; Newman, 2003), networks of occupational mobility (Breiger, 1981), world political and economic systems (Snyder and Kick, 1979; Nemeth and Smith, 1985), networks of social support (Gottileb, 1981; Wellman and Wertley, 1990) and coalition formation (Kapferer, 1969; Thurman, 1980). 
The first group of studies investigated international trade relations in political-economic synopses. During the 1980s, there were studies using "world-system theory," which stresses the importance of global economic exchange. These studies specifically focused on the trade relationships between the "core" societies, which are the economically diversified, rich, and powerful societies that are independent, and the "periphery" societies, which are economically weaker, exploited by the core, and often in a state of "persistent poverty." It is through the notable works of Wallerstein (1974, 1979), Evans (1979), Steiber (1979), and Friedman (1982) that these societal structural positions and their international relationship, as viewed through the perspective of social network analysis, became known. The studies applied block-modeling and other clustering techniques to define the structures of social systems that group "actors" into blocks. Regarding the former, the seminal works of Synder and Kick (1979) displayed the block-model of the world system in four networks; trade flows, military aggression, diplomatic relations, and conjoint treaty memberships among the countries. Along similar lines, Steiber (1979) examined the world systems theory in the relationships between communist and capitalist countries and supported the dominance of the latter. Later in the 1990s, Smith and White (1992) estimated a quantitative network analysis of trade flows during 1965, 1970, and 1980 and quantified the structure of world economic systems and the division of labor. The alarming expansion of the core group of countries and the growing peripheralization of those remaining was the significant characteristic of the world economic system that prevailed. Hence, these studies are a perfect example of the core-semi-periphery trade relationships that exist in the network model.

The above strand of literature provides the following messages: (a) dominant trade practices by the "center" (b) high protectionism and no gains from trade for the peripheries (c) there were hardly any studies on the trade integration and growth. However, by the end of the 1990s witnessed a metamorphosis in the structure and pattern of global trade. The progressive globalization, liberalization, and technological advancements facilitated trade motto toward "gains from trade" through product fragmentation, increasing returns to scale and reaping economies of scale. The network studies that emerged in the recent years were mostly concentrated on the advanced mathematical estimations, as the trade network turned to be "complex." In a complex network model, the world is considered as a set consisting of many vertices (e.g. countries) and the edges between these vertices (e.g. countries). The evolution of the binary WTN or the World Trade Web (WTW) are studied as a binary network, where an edge between any two countries is interconnected depending on whether the trade flow is larger than a given threshold (De Benedictis and Tajoli 2011, Albert and Barabasi 2002, Serrano and Boguna 2003). However, in a binary network all interconnections are taken as equal, which may underestimate the impact of trade relationship heterogeneity. Hence, the works of Garlaschelli and Loffredo (2004) and Fagiolo et al. (2008) adopted a weighted network approach to compare the degrees 
and patterns of trade integration. These studies also discussed the differences between the properties of weighted and unweighted trade networks. More recently, there has been an effort to study the roles that different regions play in WTNs. For example, the role of BRICS in the WTN and the role of China as the factory of Asia, importing intermediate goods and exporting final products to the rest of the world. The rest of the countries in the region are local suppliers of commodities.

Kali and Reyes (2007) argue that global trade is hierarchical with a core-periphery structure. The study also brings to light the emergence of smaller countries into the network after 2000. Therefore, the study points out that the country's position in the network has a substantial implication for its economic growth. Akerman and Seim (2014) study differences in polity and arms trade. The study found that the global arms trade grew denser, more clustered, and increasingly decentralized during the study period.

Similarly, Amighini and Gorgoni (2014) also applied network analysis to examine the trade in auto parts and components of supply chain markets. The study used network analysis and found that emerging economies caused a structural change in the international organization of auto production; however, they are still peripheral. Amador and Cabral (2016) also analyzed the trade-in value-added applying networks. Their study demonstrates that the networks of GVCs are centralized and asymmetric using data from the world input-output database for major European countries and a few select Asian countries.

There is also theoretical and empirical literature that focuses on trade integration and its impact on developing and developed countries. Balassa (1961), Kahnert et al. (1969), Allen (1963), and most other theoretical works stress the elimination of barriers to trade and promotion of economic integration. Available literature also analyzed the impact of trade integration on economic growth and revenue. The works of Rodrik and Rodriguez (2000) and Kraay and Dollar (2004) mainly emphasized the effect of trade integration on economic growth. In contrast, Frankel and Romer (1999) analyzed the impact of trade integration on revenue. Frankel, Stein, and Wei (1995) found that Regional Trade Agreements promote trade among member countries and are less likely to divert trade from non-member countries, thus facilitating economic welfare.

Similarly, free trade agreements in the ASEAN countries generate "trade creation" as per Urata (2010). The works of De Benedictis et al. (2011, 2014) compared the structure of trade patterns and integration ties among the countries. The authors found that the trading system has become intensely interconnected, and trade integration levels have been increasing over the years. Moreover, they found increasing and robust heterogeneity in countries' choices of trade partners.

In a recent work, Bouet et al. (2017) reviewed the methodologies for measuring trade integration, with a focus on Africa's trade integration. The authors discovered that most of the prevailing trade integration indicators are misleading. Because most of the widely applied 
trade integration measures, including primary trade-to-GDP ratios or shares of regional trade in total trade, do not account for many of the determinants of trade. Hence, the notable finding of the study is that a single indicator is insufficient to capture a country's level of trade integration correctly. Therefore, a set of indicators that are as diverse as they are complementary should be applied to measure trade integration. Another recent work by Pérez-Oviedo et al. (2018) analyzed the position and networks of South American countries in global trade networks during the period between 1992 and 2014. This study found that: (i) there is more intra-block industrial trade among South American trading blocs; (ii) the core of the region consists of the US and China as main actors, followed by Germany, France, the UK, Italy, Japan, and the Netherlands; (iii) none of the South American countries were positioned in the core of the global trade network; and (iv) China's emergence toward the "center" was referred to as an Asian giant by the authors.

\section{Data}

To address research issues we collected data on bilateral trade in goods of the world's top 50 countries, including both developed and developing countries. The countries were chosen based on their GDP sizes and were then divided into nine regions (i.e. East Asia, South East Asia, South Asia, Pacific, North America, South America, Middle East, Africa and Europe).4) We selected five specific years: 1990, 1992, 2000, 2010, and 2017; the chosen years are within a gap of 10 years beginning with the year 1990. The reasoning behind choosing these specific years instead of a time series is to compare the network maps in the decadal gap on the one hand and to understand the change in trade intensity and leadership trends on the other hand. The starting point of the analysis is 1990 , and it is from this year that complete data availability is possible. Importantly, the year 1990 was chosen because it is a year before the establishment of the WTO regime. However, as the year 1990 is a period of external shocks and structural changes, we have chosen 1992 as an additional year before the WTO. In sum, the years 1990 and 1992 represent the period before WTO regime implementations for the countries. The years after the WTO regime changes are 2000, 2010, and 2017. The year 2010 will capture the impact of the financial crisis on trade.

The data has been drawn from United Nations database COMTRADE. For a network analysis of raw bilateral trade data, we calculated an export matrix, and the value of every cell in the matrix is the mean of exports of country A to country B and imports of B from A.

4) Though Europe and Africa are continents, we did not divide them into various regions in order to make the simplify the analysis and comparison. 


\section{Methodology}

In this section, we first discuss the measurement of bilateral trade intensity indices. Second, we proceed to a detailed methodology of the network analysis model.

\section{A. Bilateral trade intensity indices: $R T P$, leadership and introversions)}

In this section, we first discuss the measurement of the bilateral trade intensity indices used for analyzing the regionalization pattern in the selected 50 countries. We analyze the bilateral trade intensity indices through revealed trade preferences (RTP) derived from intra-regional import preferences and intra-regional export preferences. Moreover, this section attempts to compute the trade leadership index $(R T L)$ to understand the emergence of countries as being a "center" or an export hub and a local supplier for the network. Similarly, we also attempt to measure the trade introversion index $\left.{ }^{6}\right)\left(R T P_{i r}\right)$ to examine the intra-regional trade patterns of countries and the trade introversion index $\left(R T P_{r r}\right)$ exclusively based on the intra-regional trade pattern of regions.7)

Trade intensity indices are said to overcome several statistical shortcomings of traditional indicators of trade, such as the well-known Balassa (1965) index of revealed comparative advantage. These measures of bilateral intensity are affected by range variability and range asymmetry and their changes are difficult to interpret (Lapadre and Tajoli 2014).8) The actual strength of bilateral trade linkages among the group of countries can be studied. The measurement of trade intensity describes the geographic distribution of a country's trade and helps analyze the strength of bilateral ties. There are various indicators, such as size, geographical distance, structural characteristics, etc. However, cross-country comparisons are limited in these measures due to size differences between the countries. The trade intensity index caters to this limitation by measuring the trade between country A and B to country B's average trade share across all countries of the world (Li and Edmonds, 2010). Kunimoto (1977) and Brown (1949) take into account actual bilateral trade flows and the hypothetical trade value and reach a situation of geographic neutrality: "The bilateral trade intensity indices aim at capturing the degree of reciprocal preference between two trading partners, which can be the result of geographic nearness and/or other proximity factors" (Lapadre and Tajoli, 2014, p. S91). The main trade

5) This section's methodology is drawn from Lapadre and Tajoli (2014).

6) Regional trade introversion is also known as revealed trade preference for countries $\left(R T P_{i r}\right)$.

7) As per Lapadre and Tajoli (2014), this measures to what extent a region's member countries tend to trade among each other more intensively with third countries.

8) Lapadre and Tajoli (2014 p. S93) discuss the limitations of bilateral intensity indices of the Balassa model and reasons to choose homogeneous bilateral intensity indices. 
indicators in this paper are described in the following sections.

\section{Revealed trade preferences $(R T P)$}

We analyze the bilateral trade intensity between countries through $R T P$, which is derived from intra-regional import preference (IMP) and intra-regional export preference (IXP). Lapadre and Tajoli (2014) define RTP as the relative bilateral trade intensity, the ratio between the difference and sum of "homogeneous" bilateral trade intensity $\left(H I_{i j}\right)$ and the "extra-bilateral" trade intensity index $\left(H E_{i j}\right)$ :

$$
\begin{aligned}
& \operatorname{RTP}_{i j}=\left(H I_{i j}-H E_{i j}\right) /\left(H I_{i j}+H E_{i j}\right) \\
& \text { and } H I_{i j}=S_{i j} / V_{i j}=\left(T_{i j} / T_{i W}\right) /\left(T_{O j} / T_{O W}\right) ; H E_{i j}=\left(1-S_{i j}\right) /\left(1-V_{i j}\right),
\end{aligned}
$$

where $S_{i j}$ is the partner country $j$ 's share of the reporting country $i$ 's total trade, and $V_{i j}$ is its share of world trade. Similarly, $T_{i j}$ is the total bilateral trade between reporting country $i$ and partner country $j, T_{i W}$ is the trade between reporting country $i$ and the world, $T_{O j}$ is the trade between country $j$ and the world (excluding country $i$ ), and $T_{O W}$ is the total world trade. The index of RTP ranges from -1 (no bilateral trade) to 1 (only bilateral trade). If it is equal to zero, it is called geographical neutrality.

To analyze the inter-regional trade preference (across the region, $r$ ), the Equation 1 can be modified as Regional trade introversion or $R T P_{i r}$ :

$$
R T P_{i r}=\left(H I_{i r}-H E_{i r}\right) /\left(H I_{i r}+H E_{i r}\right)
$$

where $H I_{i r}$ is the weighted average of the corresponding bilateral trade indices between country $i$ and its regional partners. It measures the extent to which a region's member country trades more actively within a region than outside of it.

Similarly, to measure the intra-regional trade preference (with regions), we compute $R T P_{r r}$ :

$$
R T P_{r r}=\left(H I_{r r}-H E_{r r}\right) /\left(H I_{r r}+H E_{r r}\right)
$$

where $H I_{r r}=\sum_{i=j}^{n} \sum_{j=i}^{n} H I k_{i} k_{j} W k_{i} k_{j}$ and $\left(H E_{r r}=\sum_{i=j}^{n} \sum_{j=i}^{n} H E k_{i} k_{j} W k_{i} k_{j}\right.$ and $k_{1}, k_{2}, k_{3}, \ldots .$. $k_{n}$ are the countries in region $K$.

If $R T P_{r r}$ approaches 1 , the countries within the region trade more, indicating a high trade introversion. Intra-regional trade introversion measures the extent to which a region tends to 
trade with outside or third countries and is not restricted to its region. For example, it measures East Asia's preference to trade with South America, North America, etc., and to not be involved in active trade within its member countries. The present study tried to quantify the "intra-regional introversion" to analyze the dominance of trade regionalization and trade integration. The previous studies did not attempt to measure this indicator in their works. Hence, we attempted to measure the same in this study.

\section{Trade leadership index $(R T L)$}

$R T L$ measures the leadership structures in the trade patterns among the countries within a region. It helps to identify the country that has emerged as the leader within the group. $R T L$ is computed with the help of revealed import and export preferences:

$$
R T L_{i r}=\left(R X P_{i r}-R M P_{i r}\right) / 2
$$

Where $R X P_{i r}$ and $R M P_{i r}$ are the revealed export or import preferences of country $i$ within a region $r$, where

$$
\begin{aligned}
& R X P_{i r}=\left(H X I_{i r}-H X E_{i r}\right) /\left(H X I_{i r}+H X E_{i r}\right) \\
& R M P_{i r}=\left(H M I_{i r}-H M E_{i r}\right) /\left(H M I_{i r}+H M E_{i r}\right) \\
& \text { and } H M I_{i j}=\left(S M_{i j} / V M_{i j}\right)=\left(T M_{i j} / T M_{i w}\right) /\left(T M_{o j} / T M_{o w}\right) \\
& H M E_{i j}=\left(1-S M_{i j}\right) /\left(1-V M_{i j}\right)
\end{aligned}
$$

If $R T L_{i r}>0$, then that country's intra-regional preference is higher for exports than for imports. In other words, in this scenario, the country prefers less to import from within the region and exports more to the region. As its import preferences are from outside the region and it exports to within the region, the country becomes the "local supplier." Whereas, if $R T L_{i r}<0$ then it became the "export hub" as its intra-regional preference is higher for imports as compared to exports. In other words, the country imports from within the region more than it exports to the rest of the world.9)

\section{B. Construction of networks}

At the outset, we constructed the trade patterns from a network perspective. First, we constructed the network variables by preparing an undirected network matrix with $N=50$ countries for the years 1990, 2000, and 2017. In order to obtain the network, the following

9) See for details Lapadre and Tajoli (2014). 
steps were applied in line with Lapadre and Tajoli (2014). An export matrix $(A)$ was calculated. The value of $A_{i j}$ denotes the average of exports from $i$ to $j$ and imports to $j$ from $i$. It is referred to as trade matrix henceforth. The trade matrix is used to calculate a matrix of the $R T P$ matrix. $R T P_{i j}$ denotes the revealed trade preference between $i$ and $j$. It is same as $R T P_{j i}$. The RTP matrix is symmetrical. The RTP matrix is used to construct an undirected graph (network). An edge exists between two nodes $i$ and $j$ if the value of $R T P_{i j}$ is greater than 0 . A threshold of 0 is considered here.

Network analysis sees the relationship between different elements in terms of nodes and edges (links connections, etc.). Nodes act as individual actors and edges are relationships between nodes. Where, out-degree is the number of outgoing edges and the in-degree is the number of incoming edges. Every node has an in-degree and an out-degree. The out-degree is the number of outgoing edges and the in-degree is the number of incoming edges. Some of the important terms and descriptions of the employed unweighted network analysis are provided in Table 1. A detailed description is also given in Appendix II.

Table 1. Terms and descriptions used in network analysis

\begin{tabular}{cl}
\hline Term & \multicolumn{1}{c}{ Description } \\
\hline Centrality & A variable that tells us about how a node is positioned in a network and how important it is. \\
\hline Degree & $\begin{array}{l}\text { Defined as the number of total edges connected with that vertex; it includes both arrows pointing toward } \\
\text { it as well as arrows going outward from it. }\end{array}$ \\
\hline In-degree & $\begin{array}{l}\text { Defined as the total number of arrows pointing toward the node; it represents import trade, that is, trade } \\
\text { flowing toward the country (vertex). }\end{array}$ \\
\hline Out-degree & $\begin{array}{l}\text { Defined as the total number of arrows pointing away from the node; it represents export trade, that } \\
\text { is, trade flowing away from the country (vertex). }\end{array}$ \\
\hline $\begin{array}{c}\text { Closeness } \\
\text { centrality }\end{array}$ & $\begin{array}{l}\text { A variable that tells how close one node (in terms of topological distance) is with respect to all other nodes. } \\
\text { The smallest path connecting country } i \text { and country } j \text { is denoted by the geodesic distance between } i \text { and } j .\end{array}$ \\
\hline $\begin{array}{c}\text { Eigenvector } \\
\text { Centrality }\end{array}$ & $\begin{array}{l}\text { Indicates how important a node is to the nodes around it; countries that carry a high value of eigenvector } \\
\text { centrality are the ones that are connected to many other countries which are, in turn, connected to many others. }\end{array}$ \\
\hline $\begin{array}{c}\text { Betweenness } \\
\text { Centrality }\end{array}$ & \begin{tabular}{l} 
The betweenness centrality for each vertex is the number of shortest paths that pass through the vertex. \\
\hline
\end{tabular}
\end{tabular}

\section{Results and Discussion}

\section{A. Trade regionalization: regional trade introversion and leadership patterns}

The trade intensity indices help us to detect a possible hierarchical structure in the geography of international trade in goods-notably, the core-periphery interconnections. Similarly, RTP analyzes intra-regional trade preferences; whereas intra-regional trade leadership explains the emergence of the "center" or export hub in the network. The trade introversion index helps 
to identify the intra-regional trade pattern of the countries.

As mentioned earlier in Section 3, the 50 countries are grouped into nine regions: Asia (East Asia, Southeast Asia and South Asia), Europe, the Americas (North and South), the Pacific, the Middle East, and Africa. The results obtained for trade intensity indices such as intra-regional import preference, intra-regional export preference, revealed trade leadership, and regional trade introversion are presented in Tables 2 through 19.

Tables 2 and 3 show the results for East Asia (Japan, South Korea, Hong Kong and China). The results show that Japan and China led the region in the 1990s and emerged as a local supplier during that time. Later, South Korea emerged as the trade leader by outpacing the former countries in the year 2000. These shifts can be attributed to a decline in intra-regional trade preferences, especially due to high import preferences in Japan and China. Most recently, in 2017, Japan and South Korea emerged as the leading players in the region. The trade introversion index highlights the emergence of China and its preference for regional trade.

Table 2. Intra-regional export and import preference of East Asia

\begin{tabular}{|c|c|c|c|c|c|c|c|c|c|c|}
\hline \multirow{2}{*}{ Country } & \multicolumn{5}{|c|}{ Intra-regional import preference } & \multicolumn{5}{|c|}{ Intra-regional export preference } \\
\hline & 1990 & 1992 & 2000 & 2010 & 2017 & 1990 & 1992 & 2000 & 2010 & 2017 \\
\hline Japan & 0.29 & 0.33 & 0.43 & 0.33 & 0.27 & 0.37 & 0.40 & 0.46 & 0.50 & 0.42 \\
\hline South Korea & 0.43 & 0.41 & 0.42 & 0.37 & 0.32 & 0.42 & 0.46 & 0.5 & 0.64 & 0.47 \\
\hline Hong Kong & 0.63 & 0.66 & 0.64 & 0.59 & 0.57 & 0.51 & 0.60 & 0.59 & 0.51 & 0.63 \\
\hline China & 0.58 & 0.33 & 0.66 & 0.66 & 0.62 & 0.67 & 0.40 & 0.66 & 0.52 & 0.5 \\
\hline
\end{tabular}

Table 3. Trade leadership and introversion of East Asia

\begin{tabular}{|c|c|c|c|c|c|c|c|c|c|c|}
\hline \multirow{2}{*}{ Country } & \multicolumn{5}{|c|}{ Revealed trade leadership } & \multicolumn{5}{|c|}{ Regional trade introversion $\left(R T P_{i r}\right)$} \\
\hline & 1990 & 1992 & 2000 & 2010 & 2017 & 1990 & 1992 & 2000 & 2010 & 2017 \\
\hline Japan & 0.04 & 0.03 & 0.01 & 0.09 & 0.07 & -0.08 & -0.07 & 0.06 & 0.03 & -0.07 \\
\hline South Korea & -0.01 & 0.02 & 0.04 & 0.07 & 0.07 & 0.05 & 0.00 & 0.10 & 0.07 & 0.00 \\
\hline Hong Kong & -0.06 & -0.03 & -0.03 & 0.02 & 0.03 & 0.26 & 0.28 & 0.34 & 0.32 & 0.28 \\
\hline China & 0.04 & 0.03 & 0.00 & -0.07 & -0.06 & 0.31 & 0.17 & 0.35 & 0.23 & 0.17 \\
\hline \multicolumn{6}{|c|}{ Regional trade introversion ( $R T P r r)$-regional } & 0.19 & 0.23 & 0.28 & 0.34 & 0.39 \\
\hline
\end{tabular}

Similarly, Tables 4 and 5 display the findings from the Southeast Asia region. It can be observed that Singapore emerged as the leader in the region over the years. It is also interesting to note that the intra-regional import share of Singapore was reduced from 0.74 to 0.58 , and further, it concentrated more on its intra-regional export preferences; whereas, the rest of the countries in the region centered on a preference for imports rather than exports. The high trade introversion index of Singapore $(0.56,0.56$ and 0.39$)$ implies that it has a preference for trading within the region as compared to outside the region. A more or less similar pattern of trade 
preferences can be observed in the case of Malaysia.

Table 4. Intra-regional export and import preference of South East Asia

\begin{tabular}{|c|c|c|c|c|c|c|c|c|c|c|}
\hline & \multicolumn{5}{|c|}{ Intra-regional Import preference } & \multicolumn{5}{|c|}{ Intra-regional export preference } \\
\hline & 1990 & 1992 & 2000 & 2010 & 2017 & 1990 & 1992 & 2000 & 2010 & 2017 \\
\hline Philippines & 0.37 & 0.34 & 0.48 & 0.62 & 0.55 & 0.13 & 0.05 & 0.51 & 0.59 & 0.37 \\
\hline Indonesia & 0.41 & 0.40 & 0.57 & 0.70 & 0.62 & 0.32 & 0.47 & 0.54 & 0.60 & 0.57 \\
\hline Thailand & 0.56 & 0.56 & 0.57 & 0.52 & 0.54 & 0.46 & 0.50 & 0.58 & 0.58 & 0.50 \\
\hline Malaysia & 0.76 & 0.74 & 0.76 & 0.74 & 0.67 & 0.77 & 0.76 & 0.74 & 0.68 & 0.65 \\
\hline Singapore & 0.74 & 0.76 & 0.75 & 0.68 & 0.58 & 0.78 & 0.78 & 0.80 & 0.77 & 0.71 \\
\hline Vietnam & & 0.54 & 0.66 & 0.52 & 0.36 & & 0.47 & 0.50 & 0.33 & 0.14 \\
\hline
\end{tabular}

Table 5. Trade leadership and introversion of South East Asia

\begin{tabular}{|c|c|c|c|c|c|c|c|c|c|c|}
\hline & \multicolumn{5}{|c|}{ Revealed trade leadership } & \multicolumn{5}{|c|}{ Regional Trade introversion $\left(R T P_{i r}\right)$} \\
\hline & 1990 & 1992 & 2000 & 2010 & 2017 & 1990 & 1992 & 2000 & 2010 & 2017 \\
\hline Philippines & -0.12 & -0.14 & 0.02 & -0.01 & -0.09 & -0.07 & -0.12 & 0.18 & 0.33 & 0.18 \\
\hline Indonesia & -0.05 & 0.03 & -0.02 & -0.05 & -0.02 & 0.02 & 0.12 & 0.25 & 0.40 & 0.32 \\
\hline Thailand & -0.05 & -0.03 & 0.00 & 0.03 & -0.02 & 0.22 & 0.23 & 0.28 & 0.26 & 0.21 \\
\hline Malaysia & 0.01 & 0.01 & -0.01 & -0.03 & -0.01 & 0.57 & 0.55 & 0.54 & 0.47 & 0.40 \\
\hline Singapore & 0.02 & 0.01 & 0.03 & 0.05 & 0.06 & 0.56 & 0.58 & 0.59 & 0.50 & 0.39 \\
\hline Vietnam & & -0.03 & -0.08 & -0.09 & -0.11 & na & 0.21 & 0.32 & 0.13 & -0.09 \\
\hline \multicolumn{6}{|c|}{ Regional trade introversion ( $R T P r r)$-regional } & 0.32 & 0.37 & 0.39 & 0.37 & 0.39 \\
\hline
\end{tabular}

Tables 6 and 7 discuss the South Asia region. It is interesting to note that India emerges as the local supplier and hub with a consistently increasing index value. Bangladesh and Pakistan show negative and declining trade leadership. However, the trade introversion index shows that Bangladesh trades within the region more than the rest of the countries, including India and Pakistan. The introversion index for India highlights the country's revealed preference to trade within the region.

Table 6. Intra-regional import and export preferences -south asia

\begin{tabular}{|c|c|c|c|c|c|c|c|c|c|c|}
\hline & \multicolumn{5}{|c|}{ Intra-regional Import preference } & \multicolumn{5}{|c|}{ Intra-regional export preference } \\
\hline & 1990 & 1992 & 2000 & 2010 & 2017 & 1990 & 1992 & 2000 & 2010 & 2017 \\
\hline Bangladesh & 0.86 & 0.89 & 0.88 & 0.81 & 0.79 & 0.45 & 0.47 & 0.33 & -0.08 & -0.28 \\
\hline India & 0.13 & 0.54 & 0.11 & -0.15 & -0.21 & 0.68 & 0.69 & 0.78 & 0.72 & 0.68 \\
\hline Pakistan & 0.27 & 0.28 & 0.51 & 0.59 & 0.29 & 0.55 & 0.74 & 0.48 & 0.33 & 0.31 \\
\hline
\end{tabular}


Table 7. Trade leadership and introversion of south asia

\begin{tabular}{|c|c|c|c|c|c|c|c|c|c|c|}
\hline & \multicolumn{5}{|c|}{ Revealed trade leadership } & \multicolumn{5}{|c|}{ Regional Trade introversion $\left(R T P_{i r}\right)$} \\
\hline & 1990 & 1992 & 2000 & 2010 & 2017 & 1990 & 1992 & 2000 & 2010 & 2017 \\
\hline Bangladesh & -0.20 & -0.21 & -0.27 & 0.81 & -0.53 & 0.63 & 0.70 & 0.63 & 0.39 & 0.32 \\
\hline India & 0.27 & 0.08 & 0.34 & -0.15 & 0.44 & 0.25 & 0.40 & 0.41 & 0.24 & 0.18 \\
\hline Pakistan & 0.14 & 0.23 & -0.02 & 0.59 & 0.01 & 0.11 & 0.32 & 0.19 & 0.17 & -0.10 \\
\hline \multicolumn{6}{|c|}{ Regional trade introversion $(R T P r r)$-regional } & 0.46 & 0.47 & 0.48 & 0.34 & 0.16 \\
\hline
\end{tabular}

While in the Pacific region (see Tables 8 and 9), which includes New Zealand and Australia, the pattern of trade leadership shows a blurry picture. Australia exhibits a positive trade leadership (0.01) in 1990 and 2000, but it dipped to a negative value $(-0.10)$ by 2017 . This might be due to its high intra-regional import preferences.

Table 8. Intra-regional import and export preferences -pacific region

\begin{tabular}{|c|c|c|c|c|c|c|c|c|c|c|}
\hline & \multicolumn{5}{|c|}{ Intra-regional Import preference } & \multicolumn{5}{|c|}{ Intra-regional export preference } \\
\hline & 1990 & 1992 & 2000 & 2010 & 2017 & 1990 & 1992 & 2000 & 2010 & 2017 \\
\hline New Zealand & 0.91 & 0.93 & 0.95 & 0.90 & 0.86 & 0.90 & 0.91 & 0.92 & 0.92 & 0.88 \\
\hline Australia & 0.90 & 0.91 & 0.92 & 0.92 & 0.88 & 0.91 & 0.93 & 0.95 & 0.90 & 0.86 \\
\hline
\end{tabular}

Table 9. Trade leadership and introversion of pacific region

\begin{tabular}{|c|c|c|c|c|c|c|c|c|c|c|}
\hline & \multicolumn{5}{|c|}{ Revealed trade leadership } & \multicolumn{5}{|c|}{ Regional Trade introversion $\left(R T P_{i r}\right)$} \\
\hline & 1990 & 1992 & 2000 & 2010 & 2017 & 1990 & 1992 & 2000 & 2010 & 2017 \\
\hline New Zealand & -0.010 & -0.009 & -0.010 & 0.009 & 0.010 & 0.810 & 0.848 & 0.870 & 0.823 & 0.740 \\
\hline Australia & 0.010 & 0.009 & 0.010 & -0.009 & -0.010 & 0.810 & 0.848 & 0.870 & 0.823 & 0.740 \\
\hline \multicolumn{6}{|c|}{ Regional trade introversion $(R T P r r)$-regional } & 0.81 & 0.83 & 0.87 & 0.86 & 0.74 \\
\hline
\end{tabular}

Unlike other regions in the study, South America reveals a different picture (see Tables 10 and 11). The countries in the region consist of Colombia, Brazil, Chile, Argentina, and Peru. The revealed trade leadership is comparatively low, and it is almost dominated by Argentina. Similarly, trade introversion is very high for all years between 1990 and 2017 for Argentina.

Table 10. Intra-regional import and export preferences -south america

\begin{tabular}{|c|c|c|c|c|c|c|c|c|c|c|}
\hline & \multicolumn{5}{|c|}{ Intra-regional Import preference } & \multicolumn{5}{|c|}{ Intra-regional export preference } \\
\hline & 1990 & 1992 & 2000 & 2010 & 2017 & 1990 & 1992 & 2000 & 2010 & 2017 \\
\hline Colombia & 0.59 & 0.69 & 0.74 & 0.69 & 0.62 & 0.65 & 0.71 & 0.68 & 0.65 & 0.72 \\
\hline Brazil & 0.86 & 0.88 & 0.90 & 0.80 & 0.80 & 0.77 & 0.88 & 0.91 & 0.86 & 0.84 \\
\hline Chile & 0.84 & 0.86 & 0.90 & 0.82 & 0.78 & 0.80 & 0.82 & 0.79 & 0.66 & 0.68 \\
\hline Argentina & 0.84 & 0.91 & 0.93 & 0.90 & 0.89 & 0.91 & 0.93 & 0.95 & 0.90 & 0.88 \\
\hline Peru & 0.84 & 0.87 & 0.87 & 0.79 & 0.77 & 0.76 & 0.78 & 0.72 & 0.61 & 0.59 \\
\hline
\end{tabular}


For the rest of the countries in the region intra-regional export preferences outweigh imports.

Table 11. Trade leadership and introversion of south america

\begin{tabular}{|c|c|c|c|c|c|c|c|c|c|c|}
\hline & \multicolumn{5}{|c|}{ Revealed trade leadership } & \multicolumn{5}{|c|}{ Regional Trade introversion $\left(R T P_{i r}\right)$} \\
\hline & 1990 & 1992 & 2000 & 2010 & 2017 & 1990 & 1992 & 2000 & 2010 & 2017 \\
\hline Colombia & 0.03 & 0.01 & -0.03 & -0.02 & 0.05 & 0.35 & 0.47 & 0.49 & 0.43 & 0.42 \\
\hline Brazil & -0.04 & 0.00 & 0.00 & 0.03 & 0.02 & 0.65 & 0.78 & 0.82 & 0.69 & 0.68 \\
\hline Chile & -0.02 & -0.02 & -0.06 & -0.08 & -0.05 & 0.67 & 0.70 & 0.74 & 0.56 & 0.53 \\
\hline Argentina & 0.03 & 0.01 & 0.01 & 0.00 & 0.00 & 0.77 & 0.84 & 0.89 & 0.81 & 0.78 \\
\hline Peru & -0.04 & -0.05 & -0.08 & -0.09 & -0.09 & 0.64 & 0.71 & 0.67 & 0.50 & 0.47 \\
\hline \multicolumn{6}{|c|}{ Regional trade introversion $(R T P r r)$-regional } & 0.65 & 0.70 & 0.76 & 0.70 & 0.61 \\
\hline
\end{tabular}

With the case of North America, we select three countries (Mexico, Canada and the US). We can observe that regional introversion is on the highest end for all these nations (see Tables 12 and 13). The US's trade introversion remains very high, ranging from 0.74 to 0.81 from 1990 to 2000 . However, by 2017 , the index was reduced to 0.75 , which might be due to a reduction in regional trade. It could also be because of an increase in intra-regional import preferences and a decrease in export preferences. Indeed, it is reflected in the leadership measurement as well, where it is found to be negative for the US. Mexico emerged as the local supplier of the region with a very meager share in the region. Canada emerged as a leader in the region with a positive and consistent indicator in leadership.

Table 12. Intra-regional import and export preferences -north america

\begin{tabular}{|c|c|c|c|c|c|c|c|c|c|c|}
\hline & \multicolumn{5}{|c|}{ Intra-regional Import preference } & \multicolumn{5}{|c|}{ Intra-regional export preference } \\
\hline & 1990 & 1992 & 2000 & 2010 & 2017 & 1990 & 1992 & 2000 & 2010 & 2017 \\
\hline Mexico & 0.75 & 0.79 & 0.80 & 0.78 & 0.78 & 0.77 & 0.84 & 0.86 & 0.87 & 0.86 \\
\hline Canada & 0.86 & 0.87 & 0.84 & 0.84 & 0.82 & 0.86 & 0.87 & 0.87 & 0.86 & 0.84 \\
\hline USA & 0.89 & 0.92 & 0.94 & 0.92 & 0.91 & 0.89 & 0.90 & 0.91 & 0.89 & 0.88 \\
\hline
\end{tabular}

Table 13. Trade leadership and introversion of north america

\begin{tabular}{|c|c|c|c|c|c|c|c|c|c|c|}
\hline & \multicolumn{5}{|c|}{ Revealed trade leadership } & \multicolumn{5}{|c|}{ Regional Trade introversion $\left(R T P_{i r}\right)$} \\
\hline & 1990 & 1992 & 2000 & 2010 & 2017 & 1990 & 1992 & 2000 & 2010 & 2017 \\
\hline Mexico & 0.01 & 0.02 & 0.03 & 0.04 & 0.04 & 0.51 & 0.61 & 0.64 & 0.65 & 0.63 \\
\hline Canada & 0.00 & 0.00 & 0.01 & 0.01 & 0.01 & 0.68 & 0.71 & 0.69 & 0.68 & 0.64 \\
\hline USA & 0.00 & -0.01 & -0.01 & -0.02 & -0.02 & 0.74 & 0.79 & 0.81 & 0.78 & 0.75 \\
\hline \multicolumn{6}{|c|}{ Regional trade introversion $\left(R T P_{i r}\right)$-regional } & 0.61 & 0.67 & 0.69 & 0.72 & 0.66 \\
\hline
\end{tabular}

The European region consists of 19 countries (see Tables 14 and 15). The introversion and 
leadership results display a negative value for most countries. In the case of regional trade leadership, in the 1990s, Romania emerged as the leading country (0.11). Conversely, it fell to zero during the 2000-2017 period. At the same time, we also see the emergence of the Netherlands in the year 2000 with 0.07 , and stabilizing the same until 2017. If we take the introversion index, France and Germany prefer to trade more in the region compared with others. However, more negative values also reveal the fact that most European countries hardly trade within the region.

Table 14. Intra-regional import and export preferences -europe

\begin{tabular}{|c|c|c|c|c|c|c|c|c|c|c|}
\hline \multirow{2}{*}{ Country } & \multicolumn{5}{|c|}{ Intra-regional Import preference } & \multicolumn{5}{|c|}{ Intra-regional export preference } \\
\hline & 1990 & 1992 & 2000 & 2010 & 2017 & 1990 & 1992 & 2000 & 2010 & 2017 \\
\hline Netherlands & 0.33 & 0.29 & 0.28 & 0.29 & 0.31 & 0.43 & 0.39 & 0.42 & 0.42 & 0.45 \\
\hline Switzerland & 0.34 & 0.35 & 0.35 & 0.35 & 0.34 & 0.21 & 0.23 & 0.22 & 0.19 & 0.15 \\
\hline Norway & 0.34 & 0.27 & 0.30 & 0.31 & 0.31 & 0.35 & 0.31 & 0.33 & 0.35 & 0.41 \\
\hline Germany & & 0.45 & 0.42 & 0.36 & 0.45 & & 0.45 & 0.40 & 0.42 & 0.42 \\
\hline Sweden & 0.34 & 0.30 & 0.35 & 0.45 & 0.42 & 0.31 & 0.26 & 0.26 & 0.41 & 0.35 \\
\hline Belgium & 0.38 & nil & 0.34 & 0.38 & 0.37 & 0.42 & nil & 0.37 & 0.30 & 0.43 \\
\hline Romania & -0.03 & 0.26 & 0.36 & 0.36 & 0.42 & 0.19 & 0.23 & 0.36 & 0.38 & 0.41 \\
\hline Denmark & 0.35 & 0.32 & 0.35 & 0.38 & 0.39 & 0.34 & 0.31 & 0.32 & 0.39 & 0.35 \\
\hline France & 0.44 & 0.38 & 0.39 & 0.36 & 0.41 & 0.43 & 0.37 & 0.38 & 0.32 & 0.38 \\
\hline Italy & 0.41 & 0.38 & 0.36 & 0.39 & 0.39 & 0.36 & 0.33 & 0.31 & 0.36 & 0.33 \\
\hline Austria & 0.33 & 0.37 & 0.38 & 0.36 & 0.42 & 0.33 & 0.36 & 0.35 & 0.33 & 0.37 \\
\hline Poland & 0.20 & 0.33 & 0.36 & 0.43 & 0.37 & 0.30 & 0.34 & 0.38 & 0.36 & 0.43 \\
\hline Finland & 0.33 & 0.29 & 0.31 & 0.37 & 0.40 & 0.33 & 0.29 & 0.27 & 0.42 & 0.32 \\
\hline Great Britain & 0.35 & 0.28 & 0.27 & 0.34 & 0.32 & 0.32 & 0.28 & 0.30 & 0.27 & 0.30 \\
\hline Spain & 0.34 & 0.30 & 0.34 & 0.27 & 0.33 & 0.38 & 0.34 & 0.37 & 0.28 & 0.40 \\
\hline Turkey & 0.16 & 0.17 & 0.28 & 0.31 & 0.20 & 0.23 & 0.26 & 0.29 & 0.37 & 0.30 \\
\hline Russia & & nil & 0.25 & 0.23 & 0.14 & & nil & 0.23 & 0.28 & 0.21 \\
\hline Ireland & 0.34 & 0.26 & 0.24 & 0.21 & 0.32 & 0.36 & 0.30 & 0.25 & 0.26 & 0.21 \\
\hline Portugal & 0.37 & 0.33 & 0.35 & 0.31 & 0.40 & 0.39 & 0.35 & 0.38 & 0.23 & 0.40 \\
\hline
\end{tabular}

The Middle East consists of Iran, Israel, Saudi Arabia, the UAE, and Egypt (see Tables 16 and 17). The local supplier and hub in the region during 1990 was Egypt, during 2000 and 2017 it was the UAE. The emergence of the UAE is given in Table 16. Moreover, the regional trade introversion of the UAE, Iran, and Saudi Arabia shows the countries' preference to trade within the region rather than outside the region. Finally, the African region includes only two countries; they are Nigeria and South Africa (see Tables 18 and 19). The leadership index indicates that the negative values imply no leadership patterns. 
26 Journal of Economic Integration Vol. 35, No. 1

Table 15. Trade leadership and introversion of europe

\begin{tabular}{|c|c|c|c|c|c|c|c|c|c|c|}
\hline & \multicolumn{5}{|c|}{ Revealed Trade Leadership } & \multicolumn{5}{|c|}{ Regional Trade Introversion } \\
\hline & 1990 & 1992 & 2000 & 2010 & 2017 & 1990 & 1992 & 2000 & 2010 & 2017 \\
\hline Netherlands & 0.05 & 0.05 & 0.07 & 0.06 & 0.07 & 0.01 & 0.06 & -0.02 & -0.01 & 0.02 \\
\hline Switzerland & -0.07 & -0.06 & -0.06 & -0.08 & -0.09 & -0.10 & -0.08 & -0.08 & -0.09 & -0.12 \\
\hline Norway & 0.01 & 0.02 & 0.01 & 0.02 & 0.05 & -0.02 & 0.02 & -0.05 & -0.02 & 0.01 \\
\hline Germany & & 0.00 & -0.01 & 0.03 & -0.02 & & 0.03 & 0.02 & 0.04 & 0.06 \\
\hline Sweden & -0.02 & -0.02 & -0.04 & -0.02 & -0.04 & -0.05 & -0.02 & -0.06 & 0.05 & 0.03 \\
\hline Belgium & 0.02 & nil & 0.02 & -0.04 & 0.03 & 0.03 & -0.04 & -0.01 & -0.02 & 0.04 \\
\hline Romania & 0.11 & -0.02 & 0.00 & 0.01 & 0.00 & -0.28 & 0.01 & 0.00 & 0.01 & 0.07 \\
\hline Denmark & -0.01 & -0.01 & -0.02 & 0.01 & -0.02 & -0.02 & 0.01 & -0.03 & 0.03 & 0.02 \\
\hline France & -0.01 & -0.01 & -0.01 & -0.02 & -0.02 & 0.06 & -0.02 & 0.00 & -0.02 & 0.03 \\
\hline Italy & -0.03 & -0.02 & -0.02 & -0.02 & -0.03 & 0.01 & -0.02 & -0.04 & 0.01 & 0.00 \\
\hline Austria & 0.00 & -0.01 & -0.01 & -0.02 & -0.03 & -0.03 & -0.02 & 0.01 & -0.03 & 0.05 \\
\hline Poland & 0.05 & 0.00 & 0.01 & -0.03 & 0.03 & -0.11 & -0.03 & 0.01 & 0.05 & 0.05 \\
\hline Finland & 0.00 & 0.00 & -0.02 & 0.03 & -0.04 & -0.04 & 0.03 & -0.08 & 0.04 & 0.01 \\
\hline Great Britain & -0.02 & 0.00 & 0.01 & -0.03 & -0.01 & -0.06 & -0.03 & -0.11 & -0.05 & -0.06 \\
\hline Spain & 0.02 & 0.02 & 0.01 & 0.00 & 0.03 & -0.02 & 0.00 & -0.02 & -0.11 & 0.00 \\
\hline Turkey & 0.04 & 0.05 & 0.01 & 0.03 & 0.05 & -0.19 & 0.03 & -0.09 & -0.03 & -0.12 \\
\hline Russia & & nil & -0.01 & 0.03 & 0.04 & & 0.03 & -0.13 & -0.12 & -0.19 \\
\hline Ireland & 0.01 & 0.02 & 0.00 & 0.03 & -0.05 & -0.01 & 0.03 & -0.13 & -0.13 & -0.12 \\
\hline Portugal & 0.01 & 0.01 & 0.01 & -0.04 & 0.00 & 0.02 & -0.04 & 0.01 & -0.11 & 0.06 \\
\hline Regi & trade & oversio & $R T P r r)$ & egional & & -0.05 & -0.04 & -0.08 & -0.06 & 0.02 \\
\hline
\end{tabular}

Table 16. Intra-regional import and export preferences-middle east

\begin{tabular}{|c|c|c|c|c|c|c|c|c|c|c|}
\hline & \multicolumn{5}{|c|}{ Intra-regional Import preference } & \multicolumn{5}{|c|}{ Intra-regional export preference } \\
\hline & 1990 & 1992 & 2000 & 2010 & 2017 & 1990 & 1992 & 2000 & 2010 & 2017 \\
\hline Iran & NA & NA & 0.78 & 0.83 & 0.79 & NA & NA & 0.43 & 0.31 & 0.55 \\
\hline Israel & 0.55 & 0.63 & 0.55 & -0.69 & 0.6 & 0.46 & 0.44 & 0.45 & -0.84 & 0.31 \\
\hline Saudi Arabia & 0.24 & 0.39 & 0.55 & 0.49 & 0.79 & 0.37 & 0.48 & 0.57 & 0.33 & 0.47 \\
\hline UAE & 0.42 & 0.55 & 0.47 & 0.42 & 0.51 & 0.46 & 0.30 & 0.74 & 0.80 & 0.85 \\
\hline Egypt & 0.27 & -0.27 & 0.45 & 0.35 & 0.56 & 0.53 & 0.70 & 0.65 & 0.66 & 0.74 \\
\hline
\end{tabular}

Table 17. Trade leadership and introversion of middle east

\begin{tabular}{|c|c|c|c|c|c|c|c|c|c|c|}
\hline & \multicolumn{5}{|c|}{ Revealed Trade Leadership } & \multicolumn{5}{|c|}{ Regional Trade Introversion } \\
\hline & 1990 & 1992 & 2000 & 2010 & 2017 & 1990 & 1992 & 2000 & 2010 & 2017 \\
\hline Iran & NA & NA & -0.17 & -0.26 & -0.12 & NA & NA & 0.41 & 0.50 & 0.49 \\
\hline Israel & -0.05 & -0.09 & -0.05 & -0.08 & -0.15 & 0.24 & NA & 0.2 & -0.88 & 0.19 \\
\hline Saudi Arabia & 0.07 & 0.05 & 0.01 & -0.08 & -0.16 & -0.02 & NA & 0.28 & 0.08 & 0.39 \\
\hline UAE & 0.02 & -0.12 & 0.13 & 0.19 & 0.17 & 0.08 & NA & 0.37 & 0.44 & 0.52 \\
\hline Egypt & 0.13 & 0.49 & 0.1 & 0.15 & 0.09 & 0.05 & NA & 0.22 & 0.17 & 0.36 \\
\hline \multicolumn{6}{|c|}{ Regional trade introversion $(R T P r r)$-regional } & 0.11 & & 0.24 & 0.30 & 0.37 \\
\hline
\end{tabular}


Table 18. Intra-regional import and export preferences-africa

\begin{tabular}{|c|c|c|c|c|c|c|c|c|c|c|}
\hline & \multicolumn{5}{|c|}{ Intra-regional Import preference } & \multicolumn{5}{|c|}{ Intra-regional export preference } \\
\hline & 1990 & 1992 & 2000 & 2010 & 2017 & 1990 & 1992 & 2000 & 2010 & 2017 \\
\hline South Africa & NA & NA & 0.5 & 0.46 & 0.42 & NA & NA & 0.37 & 0.64 & 0.8 \\
\hline Nigeria & NA & NA & 0.37 & 0.64 & 0.8 & NA & NA & 0.5 & 0.46 & 0.42 \\
\hline
\end{tabular}

Table 19. Trade leadership and introversion of africa

\begin{tabular}{|c|c|c|c|c|c|c|c|c|c|c|}
\hline & \multicolumn{5}{|c|}{ Revealed Trade leadership } & \multicolumn{5}{|c|}{ Regional Trade introversion } \\
\hline & 1990 & 1992 & 2000 & 2012 & 2017 & 1990 & 1992 & 2000 & 2010 & 2017 \\
\hline South Africa & NA & NA & -0.07 & 0.09 & 0.19 & NA & NA & 0.08 & 0.33 & 0.50 \\
\hline Nigeria & NA & NA & 0.07 & -0.09 & -0.19 & NA & NA & 0.08 & 0.33 & 0.50 \\
\hline
\end{tabular}

\section{B. Results and discussions: network analysis}

The pattern of network formation can be well understood from the metrics listed in Table 20. At the outset, total trade density increased from 0.115 in 1990 to 0.127 in 2000 . However, in the year 2017 there was a decline in density to 0.116 . The increase in trade density in 2000 might be due to the trade facilitation measures of the WTO. However, the post-2000 period was characterized by low density, perhaps because of more focused regional trade and trade wars (tariffs).

Table 20. The network metrics

\begin{tabular}{cccc}
\hline Metrics & 1990 & 2000 & 2017 \\
\hline Density & 0.115 & 0.127 & 0.116 \\
Degree Centrality & 0.115 & 0.127 & 0.116 \\
Closeness Centrality & 0.343 & 0.360 & 0.336 \\
Eigenvector Centrality & 0.117 & 0.114 & 0.110 \\
Betweenness Centrality & 0.050 & 0.039 & 0.043 \\
Clustering coefficient & 0.370 & 0.420 & 0.487 \\
\hline
\end{tabular}

The degree centrality analyzes the position of the nodes in the network. It tells how many neighbors are around a node and the interconnectedness of a central point to different edges (peripheries). The centrality score in a network map lies between 0 and 1 . The higher the variation in the degree of vertices implies high centralization of a network. Table 20 shows that the degree centrality first increased in the year 2000 and later decreased in 2017. The value during 1990 is 0.115 ; it increased to 0.127 in 2000 and decreased to 0.116 in 2017, implying that the countries are less interconnected in 2017. This could be because of the reforms initiated by the WTO after its formation in 1995. These interventions and polices could facilitate rising 
trade integration. However, the years close to 2017 mark a visible reduction in integration. Still, the degree centrality is often criticized since it considers only direct ties with the "center" node or its neighbors. It does not prioritize indirect ties. Hence, it is called the local centrality.

In a way, closeness centrality metric is also known as global centrality as it considers the direct and indirect ties among the network nodes. It emphasizes the topological distance from the center to all other nodes in the network. The shortest path between two countries is termed as geodesic distance. The results in Table 20 show that the degree centrality first increased in the year 2000 and later decreased in 2017. During the 1990s, the closeness centrality was 0.34 , and it increased to 0.36 by 2000 and was reduced to 0.33 in 2017 . This indicates the network ties, in terms of geodesic distance, decreased by 2017 in comparison to 2000. This implies that the network spread effect is high and that closeness is low among the countries.

Similarly, the eigenvector centrality measures the influence of a node in a network. Relative scoring is assigned to nodes in the network. The connections to high scores of the nodes lead more to the score of the node than the parallel links to low-scoring nodes. A high eigenvector score means that a node is connected to many nodes, which themselves have high scores. A more precise interpretation is indicated by the median values of the metrics. The median value indicates how the central value of this metric has fared over the years throughout the globe. The median value in 1990 is 0.081 ; in 2000, it is 0.102 , and in 2017, it is 0.0784 . The median value over the years indicates that the metric fell in 2017 as compared to 2000 . The value in 2017 is lowest among all the years considered. Hence, it is implied that trade became more and more decentralized. The relative importance of all countries is more or less equal.

Similarly, the results from betweenness centrality, which measures dependency, have fallen to 0.043 in 2017 from 0.050 in 1990. This implies that there is weak trade integration or trade linkage between the center and the periphery. Betweenness also measures the number of times a node lies on the shortest path between other nodes. Therefore, the betweenness metric points to increasing trade regionalization and less interconnectedness in the network.

The clustering coefficient differs from measures of centrality, and is similar to network density and not trade density. When the interlinkages are dense, the clustering coefficient will be high. In our result, the value of the clustering coefficient shows an increase from 0.370 in 1990 to 0.420 by 2000 and a further increase to 0.487 by 2017, indicating toward trade regionalization.

Even after two decades of liberalization measures, there is no marked improvement in trade intensity. Compared with progressive trade developments in 2000, the year 2017 shows a reduction in the overall trade density, interconnectedness, closeness, and each country's relative importance in the network. On the other hand, we see trade became more asymmetric, with increased clustering, indicating more trade regionalization among the countries in the network. However, the results also indicate that there was no improvement in proximity among them.

Network representation: presentation through graphs 
In this section, we present network visualizations graphs for goods trade between 50 countries for the years 1990, 2000, and 2017. We covered both developed and developing regions. Figure 2 depicts a network visualization of goods trade of unweighted trade ties.

Figure 2. Trade network graph: year 1990

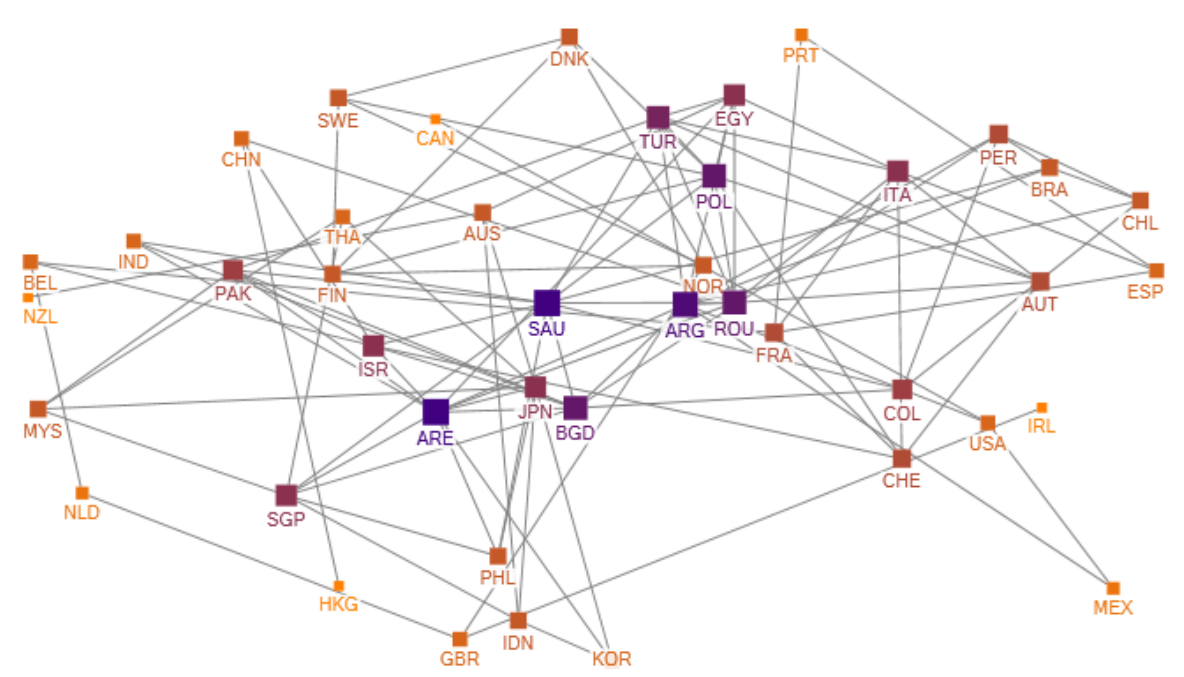

In 1990, the countries in the core include Romania, Saudi Arabia, Argentina, Poland, Norway, and the UAE. The core countries tend to have bigger nodes, are located in the center of the network (core or hub), and are considered the major suppliers of goods to the peripheral countries. The other two countries in the core-Bangladesh and France-import more and export less. The peripheral countries are located in the outer layers of the network. The peripheral countries during this period include India, China, Portugal, Mexico, Ireland, Hong Kong, the Netherlands, Canada, New Zealand, the US, Thailand, Belgium, Korea Rep, Spain, and the UK.

Figure 3 shows the network visualization graph for the year 2000. The core group of countries in the network map is Iran, Italy, Saudi Arabia, Indonesia, India, Japan, Germany, Russia, Nigeria, Singapore, Korea, and Italy. However, countries such as Nigeria, Indonesia, Germany, Russia, Italy, and Iran show more import flows. This year also marked the repositioning of many emerging economies, such as India and Indonesia, toward the center from their peripheries in 1990. Henceforth, this repositioning led to a profound restriction of the WTN.

The results of the 2017 trade network graphs (Figure 4) show an interesting transition. The major countries who reached to the core group consists: Saudi Arabia, Italy, Poland, Netherlands, Turkey, India, Germany, Thailand, Sweden, the US, and Philippines. Whereas, the peripheral countries in the sample consists of Canada, Hong Kong, Ireland, the UK, New Zealand, and Mexico. 
Figure 3. Trade network graph: year 2000

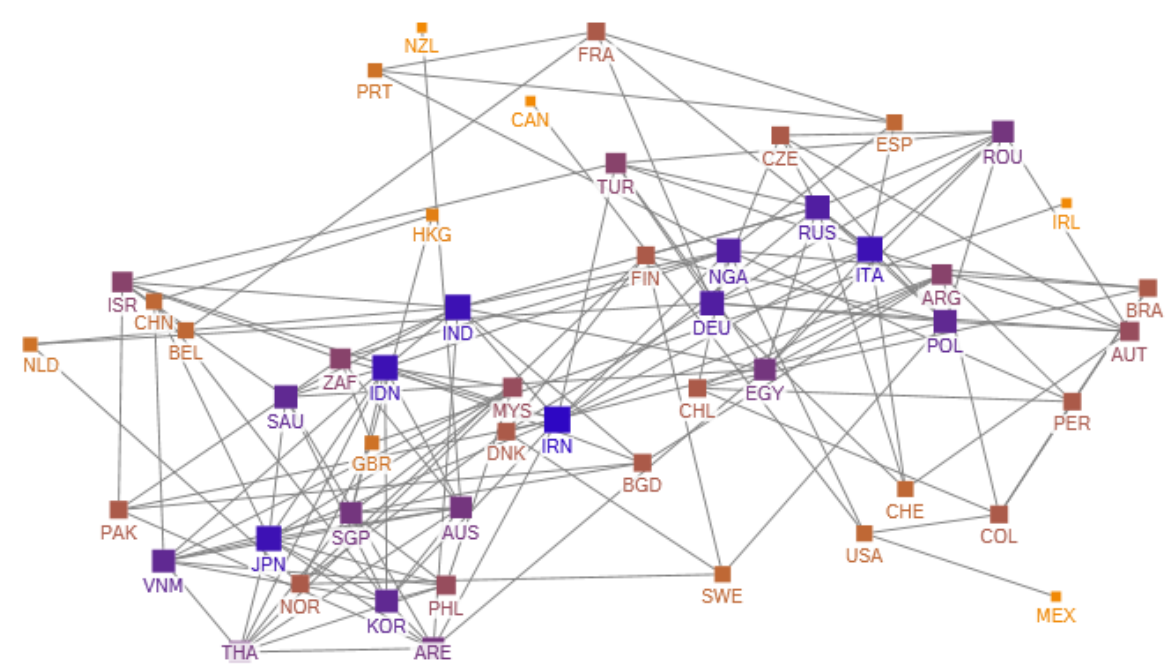

Figure 4. Trade network graph: year 2017

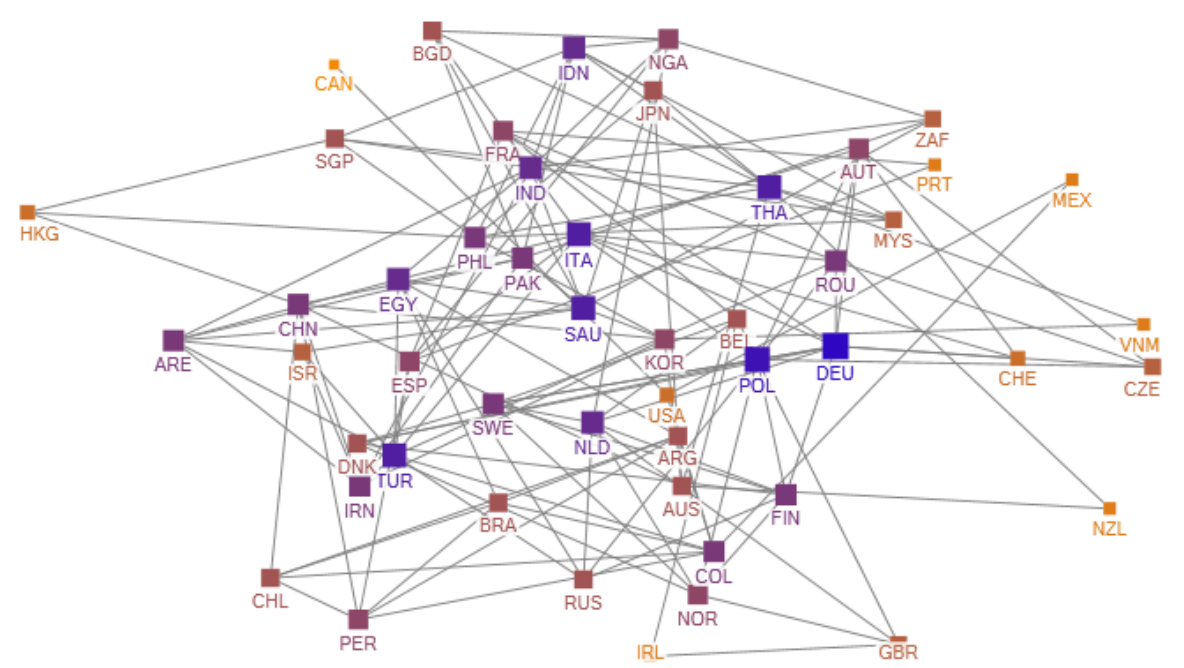

\section{Conclusion}

Over many years, most of the countries have opened their economies to international trade. Thus, trade integration has allowed countries to benefit from specialization, gains from economies of scale, product variety, and increased competition. However, the following questions arise: has deeper trade integration benefited developing countries? Has trade intensity among the 
countries increased? What is the pattern of trade leadership and regionalization? This paper attempted to connect the "trio" of trade integration, leadership, and regionalization through the lens of network analysis.

For the same, we empirically analyzed a selected 50 countries encompassing both developed and developing nations, sub-divided into nine world regions. The data for five specific years have been selected for the study, 1990, 2000, and 2017. This paper discusses the results in two dimensions in the context of the center-periphery. First, it tries to answer the question of whether trade integration leads to leadership and regionalization. Second, it measures the intensity of trade integration through network analysis. It will broadly discuss the patterns of trade over the past two decades (in the aftermath of trade liberalization). Through indicators such as density, connectivity, closeness, and betweenness, it measures the depth of trade interconnectedness among the countries.

The first result concerns the possibility of regionalization as measured by regional introversion indices. All nine regions show mixed results. Out of the nine regions, the majority of regions exhibited an increasing trend in the introversion index (Southeast Asia, the Pacific, North America, South America, the Middle East and Africa). The index has fallen for South Asia and has been stagnant for East Asia and Europe over the years. Hence, the forces driving regional integration are stronger for the sample countries, supporting the evidence of regionalization. However, trade regionalization is mainly found within the developed regions of the north such as the Americas and the Pacific and it is rather weak for the regions of Asia, Europe, the Middle East, and Africa. These findings are in contrast to Lapadre and Tajoli (2014), who found a trade diverting effect of regional integration and no regionalization.

Now regarding trade leadership patterns, the trend is mixed. Regions such as East Asia, Europe, South Asia, and the Middle East demonstrate a fall in trade leadership patterns. In the case of East Asia, there is a change in trade leadership from Japan and China in 1990 to Japan and South Korea by 2017. In South Asia, India emerges as the leader throughout the 1990-2017 period. Importantly, regions such as Southeast Asia, the Pacific, North America, and South America show a consistent improvement in trade leadership. Singapore is the dominant trade leader for Southeast Asia from 1990 to 2017 and Australia for the Pacific region. Regarding North America, it is Argentina, and for South America, the leader is Mexico. Similarly, for the region of the Middle East, the UAE emerged as the trade leader. Thus, in terms of trade leadership, some countries emerge as the dominant trade leaders (with consistent growth as leader and local supplier), for example, Singapore, Japan, Argentina, Australia, Netherlands, India, and the Netherlands. Trade liberalization reduced the gap between the center-periphery, and many Asian developing countries emerged as the leaders and export hubs of goods in the global market owing to the impact of trade diversification and fragmentation leading to trade in intermediaries. 
Second, this paper tried to connect trade intensity and the network model. As discussed above, trade liberalization transformed and reshaped the world trade structure. The improved export performance of many emerging economies and trade diversification are some of the merits. However, the center or the export hubs of each region do not occupy a structural position. Overall, trade density has been reduced, and trade has become more clustered and more asymmetric. Nevertheless, the clustering coefficient (i.e. trade density) shows improvement over the period between 1990 and 2017. In other words, the trade network among the countries remains static or there is no major improvement in the parameters: degree centrality (local centrality), eigenvector centrality (geodesic distance), betweenness (dependency), and closeness (global centrality). However, the results indicate that there is also no improvement in proximity, which is almost static. The new trade theories base their arguments in terms of the above. According to the results, when trade proximity improves among countries it leads to a reduction in transport costs and gains from trade. Contrarily, the paper finds that trade liberalization has not driven the lessening geodesic distance and transport costs, and thus, there have been no major gains from trade for many countries.

In the context of high trade interconnectedness, fastening intermediate product networks, and reducing trade intensity among global trade, it is challenging to frame policies that are suited to markets. There is a massive global challenge to facilitate trade integration rather than regionalization. However it is possible to accomplish this task through: (a) reducing the tariff and non-tariff restrictions among the countries; (b) reducing the transport and telecommunication costs; (c) improving the quality infrastructural development network in the countries and regions; (d) linking technology with trade; (e) promoting and implementing geography-based production centers in different regions and linking the hubs and spokes network of countries with a comparative advantage in select items; and (f) initiating a flying geese pattern of growth in key technologies in the transport system, supply chain, and logistics with the help of advanced information technology in different countries is recommended. These policies can have an impact on trade facilitation, reciprocity, and improving the market access among the countries.

\section{References}

Albert, R., and Barabási, A. L. (2002). "Statistical mechanics of complex networks." Reviews of modern physics 74, no. 1, 47.

Allen, R. L. (1963). Economic Integration: Analytical and Empirical Survey.

Amador, J., and Cabral, S. (2017). "Networks of value-added trade." The World Economy 40, no. 7, 1291-1313.

Amighini, A., and Gorgoni, S. (2014). "The international reorganisation of auto production." The World 
Economy 37, no. 7, 923-952.

Balassa, B. (1961). The theory of economic integration. Homewood, Illinois: Richard D. Irwin.

Balassa, B. (1965). "Trade liberalisation and "revealed" comparative advantage 1." The manchester school 33, no. 2, 99-123.

Baldwin, R. E., and Okubo, T. (2005). "Heterogeneous firms, agglomeration and economic geography: Spatial selection and sorting." Journal of Economic Geography 6, no. 3, 323-346.

Baldwin, R., and Venables, A. J. (2013). "Spiders and snakes: Offshoring and agglomeration in the global economy." Journal of International Economics 90, no. 2, 245-254.

Bastos, P., and Cabral, M. (2007). "The dynamics of international trade patterns." Review of World Economics 143, no. 3, 391-415.

Bouët, A., Cosnard, L., and Laborde, D. (2017). "Measuring trade integration in Africa." Journal of Economic Integration, 937-977.

Brasili, A., Epifani, P., and Helg, R. (2000). "On the dynamics of trade patterns." De economist 148, no. 2, 233-258.

Breiger, R. (1981). "Structures of economic interdependence among nations." Continuities in structural inquiry, 353-380.

De Benedictis, L., and Tajoli, L. (2011). "The world trade network." The World Economy 34, no. 8, 1417-1454.

De Benedictis, L., Nenci, S., Santoni, G., Tajoli, L., and Vicarelli, C. (2014). "Network analysis of world trade using the BACI-CEPII dataset." Global Economy Journal 14, no. 03n04, 287-343.

Deardorff, A. V. (1974). "Factor proportions and comparative advantage in the long run: Comment." Journal of Political Economy 82, no. 4, 829-833.

Dollar, D., and Kraay, A. (2003). "Institutions, trade, and growth." Journal of monetary economics 50, no. $1,133-162$.

Evans, P. (1979). "Beyond center and periphery: A comment on the contribution of the world system approach to the study of development." Sociological Inquiry 49, no. 4, 15-20.

Fagiolo, G., Reyes, J., and Schiavo, S. (2010). "The evolution of the world trade web: A weighted-network analysis." Journal of Evolutionary Economics 20, no. 4, 479-514.

Filippini, C., and Molini, V. (2003). "The determinants of East Asian trade flows: A gravity equation approach." Journal of Asian Economics 14, no. 5, 695-711.

Findlay, R. (1970). "Factor proportions and comparative advantage in the long run." Journal of Political Economy 78, no. 1, 27-34.

Frankel, J. A., and Romer, D. H. (1999). "Does trade cause growth?" American economic review 89, no. 3, 379-399.

Frankel, J., Stein, E., and Wei, S. J. (1995). "Trading blocs and the Americas: The natural, the unnatural, and the super-natural." Journal of development economics 47, no. 1, 61-95.

Friedman, E. (ed.) (1982). Ascent and decline in the world-system. London: Sage.

Fujita, M., Krugman, P. R., and Venables, A. J. (2001). The spatial economy: Cities, regions, and international trade. MIT press.

Garlaschelli, D., and Loffredo, M. I. (2004). "Fitness-dependent topological properties of the world trade web." Physical review letters 93, no. 18, 188701. 
Gottlieb, B. H. (1983). Social support strategies: Guidelines for mental health practice (Vol. 7). Sage Publications, Inc.

Hamanaka, S. (2015). "The selection of trade integration indicators: Intraregional share, intensity, homogeneous intensity, and introversion index." Asian Development Bank Economics Working Paper Series, 455.

Hoekman, B. (2015). "Trade and growth-end of an era?." The global trade slowdown: A new normal, 3-19.

Johnson, D. G. (2002). "Globalization: what it is and who benefits." Journal of Asian Economics 13, no. 4, 427-439.

Kahnert, F., P. Richards, E. Stoutjesdijk, and P. Thomopoulos. (1969). Economic integration among developing countries. Paris: Development Center of the Organization for Economic Co-operation and Development (OECD).

Kali, R., and Reyes, J. (2007). "The architecture of globalization: A network approach to international economic integration." Journal of International Business Studies 38, no. 4, 595-620.

Kapferer, B. (1969). Norms and the manipulation of relationships in a work context.

Krugman, P. (1991). Geography and trade, Cambridge, MA: MIT Press.

Krugman, P. (1991). "Increasing returns and economic geography." Journal of Political Economy 99, no. 3, 483-499.

Krugman, P. R. (1981). "Intra-industry specialization and the gains from trade." Journal of political Economy 89, no. 5, 959-973.

Kunimoto, K. (1977). "Typology of trade intensity indices." Hitotsubashi Journal of Economics 17, no. 2, $15-32$.

Lapadre, P. L., and Tajoli, L. (2014). "Emerging countries and trade regionalization: A network analysis." Journal of Policy Modeling 36, no. S, S89-S110.

Li, Y., and Edmonds, C. (2010, May). "China's Bilateral Trade Intensity.” In 2010 International Conference on E-Business and E-Government (pp. 5110-5113). IEEE.

Maddison, A. (2005). Growth and interaction in the world economy, The Roots of Modernity, Washington DC.

Marti, L., and Puertas, R. (2019). "Factors determining the trade costs of major European exporters." Maritime Economics \& Logistics, 1-10.

Mattoo, Aaditya, et al. (2013). Trade in value added: Developing new measures of cross-border trade, World Bank Group.

Melitz, M. J. (2003). "The impact of trade on intra-industry reallocations and aggregate industry productivity." econometrica 71, no. 6, 1695-1725.

Nemeth, R. J., and Smith, D. A. (1985). "International trade and world-system structure: A multiple network analysis." Review (Fernand Braudel Center) 8, no. 4, 517-560.

Newman, M. (2010). Networks: An Introduction, New York: Oxford University Press.

Nguyen, T. N. A., Pham, T. H. H., and Vallée, T. (2016). "Economic integration in ASEAN+ 3: A network analysis." Journal of economic integration, 275-325.

Pérez-Oviedo, W., Cajas-Guijarro, J., and Vallejo, M. C. (2018). "South America: Trade and integration in the new global trade network." In Regionalism, Development and the Post-Commodities Boom 
in South America (pp. 121-145). Palgrave Macmillan, Cham.

Rodriguez, F., and Rodrik, D. (2000). "Trade policy and economic growth: A skeptic's guide to the cross-national evidence." NBER macroeconomics annual 15, 261-325.

Serrano, M. A., and Boguñá, M. (2003). “Topology of the world trade web.” Physical Review E 68, no. $1,015101$.

Smith, D. A., and White, D. R. (1992). "Structure and dynamics of the global economy: Network analysis of international trade 1965-1980." Social forces 70, no. 4, 857-893.

Snyder, D., and Kick, E. L. (1979). "Structural position in the world system and economic growth, 1955-1970: A multiple-network analysis of transnational interactions." American journal of Sociology 84, no. 5, 1096-1126.

Steiber, S. R. (1979). "The world system and world trade: An empirical exploration of conceptual conflicts." The Sociological Quarterly 20, no. 1, 23-36.

Urata, S., and Okabe, M. (2010). "Trade creation and diversion effects of regional trade agreements on commodity trade." Discussion papers, 10007.

Wallerstein, I. (1974). "The modern world." System 1, no. 1.

Wallerstein, I. (1979). The capitalist world-economy (Vol. 2), Cambridge University Press.

Wasserman, S., and Faust, K. (1994). Social network analysis: Methods and applications (Vol. 8), Cambridge university press.

Wellman, B., and Wortley, S. (1990). "Different strokes from different folks: Community ties and social support." American journal of Sociology 96, no. 3, 558-588.

World Trade Organization (2008). World trade report, World Trade Organization. 
36 Journal of Economic Integration Vol. 35, No. 1

\section{Appendix 1: Countries and regions: sample}

\begin{tabular}{|c|c|c|c|c|c|c|c|c|}
\hline $\begin{array}{l}\text { East } \\
\text { Asia }\end{array}$ & $\begin{array}{c}\text { Southeast } \\
\text { Asia }\end{array}$ & Pacific & $\begin{array}{l}\text { South } \\
\text { America }\end{array}$ & $\begin{array}{l}\text { North } \\
\text { America }\end{array}$ & Europe & $\begin{array}{c}\text { South } \\
\text { Asia }\end{array}$ & $\begin{array}{l}\text { Middle } \\
\text { East }\end{array}$ & Africa \\
\hline $\begin{array}{l}\text { 1. China } \\
\text { 2. Hong Kong } \\
\text { 3. South Korea } \\
\text { 4. Japan }\end{array}$ & $\begin{array}{l}\text { 1. Philippines } \\
\text { 2. Indonesia } \\
\text { 3. Thailand } \\
\text { 4. Malaysia } \\
\text { 5. Singapore } \\
\text { 6. Vietnam }\end{array}$ & $\begin{array}{l}\text { 1. New Zealand } \\
\text { 2. Australia }\end{array}$ & $\begin{array}{l}\text { 1. Columbia } \\
\text { 2. Brazil } \\
\text { 3. Chile } \\
\text { 4. Argentina } \\
\text { 5. Peru }\end{array}$ & $\begin{array}{l}\text { 1. Mexico } \\
\text { 2. Canada } \\
\text { 3. US }\end{array}$ & $\begin{array}{l}\text { 1. Netherlands } \\
\text { 2. Switzerland } \\
\text { 3. Norway } \\
\text { 4. Germany } \\
\text { 5. Sweden } \\
\text { 6. Belgium } \\
\text { 7. Romania } \\
\text { 8. Denmark } \\
\text { 9. France } \\
\text { 10. Italy } \\
\text { 11. Austria } \\
\text { 12. Poland } \\
\text { 13. Finland } \\
\text { 14. UK } \\
\text { 15. Spain } \\
\text { 16. Turkey } \\
\text { 17. Russia } \\
\text { 18. Ireland } \\
\text { 19. Portugal }\end{array}$ & $\begin{array}{l}\text { 1. Bangladesh } \\
\text { 2. India } \\
\text { 3. Pakistan }\end{array}$ & $\begin{array}{l}\text { 1. Iran } \\
\text { 2. Israel } \\
\text { 3. Saudi Arabia } \\
\text { 4. UAE } \\
\text { 5. Egypt }\end{array}$ & $\begin{array}{l}\text { 1. Nigeria } \\
\text { 2. South Africa }\end{array}$ \\
\hline
\end{tabular}




\section{Appendix 2: Network terms and descriptions}

Centrality measures: this variable tells us about how a node is positioned in a network and how important it is. This is classified into multiple types.

Degree: a vertex is defined as the number of total edges connected with that vertex; it includes both arrows pointing toward it as well as arrows going away from it. More than overall value, the value of a degree is more connected the vertex than another vertex in a network. Let us say for node $i$ the degree will be given as follows:

$$
D i=j=1 N a(i \rightleftharpoons j) ; j \neq i,
$$

where $D_{i}$ means degree of $i^{\text {th }}$ node, and aij is value taken from binary matrix, and $N$ is the total number of node. $a(i j)=1$ if there is edge between node $i$ and $j$. While $a(i j)=0$ in the case of no edge between node $i$ and $j$.

In-degree: for a vertex it is defined as total number of arrows pointing toward the node. It represents import trade, that is, trade flowing toward the country (vertex). The higher the value of the in-degree, the higher the imports. For node $i$, the in-degree will be given as follows:

$$
D I i=j 1 N a(j \rightarrow i) ; j \neq i,
$$

where $a(j i)$ is only taken from $j$ toward $i$ that is arrow coming toward $i$ th node.

Out-degree: for a vertex it is defined as the total number of arrows pointing away from the node. It represents export trade, that is, trade flowing away from the country (vertex). The higher the value of the in-degree, the higher the exports. For node $i$, the out-degree will be given as follows:

$$
D O i=j 1 N a(j \rightarrow i) ; j \neq i,
$$

where $a(i>j)$ showing that arrow from node $i$ to other nodes.

Closeness centrality: it is a variable that tells that how close one node (in terms of topological distance) is with respect to all other nodes. The smallest path connecting country $i$ and country $j$ is denoted by the geodesic distance between $i$ and $j$. By taking the inverse of the average 
geodesic distance as a measure of proximity, the closeness centrality gives the high centrality scores to nodes that are located closer to the set of reachable nodes:

$$
C C(i)=1 j=1, \neq i N l(i j)
$$

where $l(i j)$ is the number of steps in the shortest path between $i$ and $j$.

Eigenvector centrality: indicates how important a node is to the nodes around it. Countries that carry a high value of eigenvector centrality are ones that are connected to many other countries, which are, in turn, connected to many others. The largest values correspond to countries in large and cohesive (high-density) sub-networks.

Betweenness centrality: In graph theory, the betweenness centrality is considered as the measure of centrality in the graph based on shortest path. In a connected graph, for every pair of vertices, there can be at least one path, which is shortest, between the vertices such that either the number of edges that the path passes through (for unweighted graphs) or the sum of the weights of the edges (for weighted graphs) is minimized. The betweenness centrality for each vertex is the number of these shortest paths that pass through the vertex. In graph theory, the betweenness centrality is considered as the measure of centrality in the graph based on shortest path. In a connected graph, for every pair of vertices, there can be at least one path that is the shortest connection between the vertices. In other words, the betweenness centrality of a vertex is the number of short paths that pass through the vertex.

The network construction requires a set of nodes and a criterion for the interactions between the countries (edges). The edges reflect the importance of the source country $x$ as a supplier for the production of exports of country $c$. 